\title{
Analisis Faktor yang Mempengaruhi Motivasi Belajar Mahasiswa Semester II Prodi PGMI STKIP Nurul Huda OKU Timur
}

\author{
Imam rodin', Nesi Anti Andini² \\ STKIP Nurul Huda Sukaraja \\ *E-mail: Imamrodin71@gmail.com
}

\begin{abstract}
Abstrak
Rendahnya motivasi belajar siswa sering dianggap sebagai penyebab rendahnya kualitas lulusan sebuah perguruan tinggi. Faktor ini bahkan menimbulkan persoalan yang dilematis, karena dengan rendahnya motivasi belajar, tidak mungkin mahasiswa dapat menguasai pembelajaran dengan baik.

Berdasarkan teori motivasi menjadi faktor paling dominan yang mempengaruhi proses dan hasil pembelajaran. Penelitian ini mengkaji faktor-faktor yang mempengaruhi motivasi belajar, diantaranya: (1) minat belajar, (2) dukungan orangtua, (3) sarana dan prasarana. Penelitian ini menggunakan pendekatan kuantitatif dengan cara pelaksanaannya adalah survei. Fokus penelitian yaitu mahasiswa PGMI STKIP Nurul Huda Sukaraja. Teknik pengumpulan data dilakukan dengan angket dan dokumentasi. Analisis data dilakukan secara interaktif. Hasil penelitian menunjukkan bahwa terdapat pengaruh antara minat, dukungan orangtua dan sarana prasarana dengan motivasi belajar mahasiswa PGMI STKIP Nurul Huda Sukaraja. Hal ini juga mengindikasikan bahwa semakin tinggi minat, dukungan orang tua dan sarana prasarana maka motivasi belajar yang dimiliki juga semakin tinggi.
\end{abstract}

Kata kunci: Minat Belajar, Dukungan Orangtua, Sarana dan Prasarana

\section{PENDAHULUAN}

Motivasi belajar merupakan keseluruhan daya penggerak baik dalam diri sendiri maupun dari luar yang menjamin kelangsungan dan memberikan arahan pada kegiatan belajar, sehingga tujuan yang dikehendaki oleh siswa dapat tercapai. Dikatakan "keselurihan daya penggerak" karena ada beberapa motif yang bersama-sama menggerakkan siswa untuk belajar (Sardiman. 2012).

Setiap siswa memiliki tingkat motivasi belajar yang berbeda-beda ketika mengikuti kegiatan pembelajaran tergantung dari apa yang ingin dicapai. Perbedaan motivasi belajar menjadi permasalahan untuk mencapai tujuan pembelajaran disekolah. Tanpa adanya tingkat motivasi belajar yang tinggi, maka pembelajaran tidak berjalan secara efektif, sehingga motivasi belajar harus diperhatikan untuk mencapai tujuan pembelajaran.

Rendahnya motivasi belajar siswa sering dianggap sebagai penyebab rendahnya kualitas lulusan sebuah perguruan tinggi. Faktor ini bahkan menimbulkan persoalan yang dilematis, karena dengan rendahnya motivasi belajar, tidak mungkin mahasiswa dapat menguasai pembelajaran dengan baik.

Motivasi belajar seseorang dipengaruhi oleh dua faktor yaitu faktor ekstrinsik meliputi lingkungan (alam, sosial), perhatian orangtua, kurikulum, pengajaran, sarana dan prasarana, fasilitas dan administrasi. Sedangkan faktor intrisik meliputi fisiologis (kondisi fisik), dan psikologis (bakat, minat, kecerdasan dan kemampuan kognitif) (Shalahudin, M. 2000).

Purwanrto (Purwanto, 2010) menekankan faktor ekstrinsik yang mempengaruhi faktor belajar mahasiswa dipengaruhi oleh dua hal yaitu lingkungan alam dan sosial (keluarga dan masyarakat). Untuk menciptakan lingkungan keluarga yang dapat memotivasi mahasiswa dalam belajar secara 
optimal maka erat kaitannya denga orangtua. Perhatian orangtua dalam memotivasi belajar anaknya merupakan faktor terpenting dalam suksesnya pembelajaran.

Banyak ditemui orangtua yang kurang perhatian dalam pendidikan putra-putrinya, mereka sibuk dengan urusan dan pekerjaan masing-masing, mereka lupa menyisihkan waktu buat anak-anaknya, mengontrol kegiatan mereka, orangtua juga lupa membantu permasalahan yang di hadapi.orangtua yang baik adalah yang mendorong aktivitas belajar bagi anak-anaknya, lembut tapi juga menetapkan batas-batasan yang fleksibel dalam mengatur tingkah laku anak-anaknya.

Seorang mahasiswa yang baik seharusnya hadir mengikuti perkulihan dengan rajin, tidak suka membolos, tekun dan penuh semangat, mengerjakan tugas dengan baik. Mereka memiliki cita-cita dan harapan yang dapat mendorong untuk belajar dengan giat dan tekun.

Sarana dan prasarana adalah segala sesuatu yang digunakan pendidik dalam ushanya dalam mencapai tujuan pendidikan yang telah di rumuskan. Sarana dan prasarana belajar meliputi ruangan, media dan peralatan untuk belajar. Sarana dan prasarana dipandang dapat membantu kearah keberhasilan kegiatan pembelajaran. Sarana yang tersedia di rumah maupun disekolah dapat membantu meningkatkan keinginan peserta didik dalam belajar.

\section{METODE/EKSPERIMEN}

Penelitian ini masuk kekelompok penelitian expost facto. expost facto adalah penelitian dimana variabel yang hendak diteliti (variabel terikat) sudah ada pada saat peneliti dilakukan, atau dengan kata lain yaitu penelit meneliti peristiwa lain tang telah terjadi dan tidak memberikan perlakuan terhadap variabel yang diteliti. ${ }^{1}$ Peneliti tidak bisa memanipulasi keadaan karena faktanya telah terjadi. Data dikumpulkan setelah semua yang dipersoalkan sudah lewat untuk menjelaskan akibat pada saat ini. Pada peneliti expost facto keterikatan antar variabel bebas (independent variabel) dengan variabel bebas (dependent variabel) sudah terjadi secara alami, dengan setting tersebut ingin menelusuri kembali apa yang menjadi faktor penyebab.

Jenis penelitian yang digunakan adalah deskriptif kuantitatif, merupakan sejak pengumpulan data, pengelolaan data, hingga penyajian semua dalam bentuk angka.

\section{HASIL DAN PEMBAHASAN \\ Hasil \\ Penelitian ini terdiri dari dua variabel penelitian yaitu variabel bebas dan variable terikat, kedua variable tersebut dibagi dalam tiga variable bebas terdiri atas minat belajar $\left(X_{1}\right)$, dukungan orang tua $\left(\mathrm{X}_{2}\right)$, sarana dan prasarana $\left(\mathrm{X}_{3}\right)$, sedangkan variable terikat berupa motivasi belajar $(\mathrm{Y})$. \\ Data hasil penelitian dari masing-masing variabel dapat dideskripsikan dengan skor tertinggi, skor terendah, rata-rata, dan standar deviasi, yang selanjutnya hasilnya dikonversikan untuk menentukan kreteria dari masing-masing variabel dengan menggunakan acuan sebagai berikut.}

Tabel 4.1. Kriteria skor variable $\mathrm{X}_{1}, \mathrm{X}_{2}, \mathrm{X}_{3}$, dan $\mathrm{Y}$

\footnotetext{
${ }^{1}$ Arikunto, 2013. Prosedur Penelitian Suatu pendekatan Praktik. Jakarta:Pt. Rineka Cipta
} 


\begin{tabular}{|l|l|}
\hline Skor & Kriteria \\
\hline$X \geq(M+1,50 . S D)$ & Sangat tinggi \\
$(M+0,50 . S D) \leq X<(M+1,50 . S D \quad)$ & Tinggi \\
$(M-0,50 . S D) \leq X<(M+0,50 . S D \quad)$ & Sedang \\
$(M-0,50 . S D) \leq X<(M \quad-1,50 . S D)$ & Rendah \\
$X<(M-1,50 . S D)$ & Sangat rendah \\
\hline
\end{tabular}

Sumber : Sutrisno, H (2000:45)

Keterangan: $M$ = rata-rata nilai

$\mathrm{SD}=$ standar deviasi

$\mathrm{X}=$ nilai skor

Berdasarkan tabel kriteria skor minat belajar di PGSD UAD di atas terdapat lima kriteria yaitu sangat tinggi berada pada skor $X \geq 32,5$, kriteria tinggi berada pada skor $27,5<X 1 \leq 32,5$, kriteria sedang berada pada skor $22,5<X 1 \leq 27,5$, criteria rendah berada pada skor $22,5<X 1 \leq 17,5$, dan sangat rendah berada pada skor $X<17,5$. Distribusi frekuensi dan persentase minat belajar mahasiswa dapat dilihat pada tabel berikut.

Tabel 4.2. Distribusi Frekuensi Skor Nilai Minat Belajar Mahasiswa PGSD

\begin{tabular}{|l|c|c|c|}
\hline Kategori & Rentang Skor & Frekuensi & Persentase \\
\hline Sangat tinggi & $32,5-40,00$ & 41 & 0,41 \\
\hline Tinggi & $27,5-32,5$ & 30 & 0,30 \\
\hline Sedang & $22,5-27,5$ & 3 & 0,03 \\
\hline Total & & 74 & 0.74 \\
\hline
\end{tabular}

Berdasarkan pada tabel di atas dapat diketahui $41 \%$ atau 41 mahasiswa PGMI memiliki minat belajar pada kategori sangat tinggi; 30\% atau 30 mahasiswa dengan kategori tinggi dan $3 \%$ atau 3 mahasiswa dalam kategori sedang kategori rendah dan sangat rendah tidak ada. Hal ini menunjukkan bahwa minat belajar mahasiswa PGMI STKIP Nurul Huda Sukaraja termasuk dalam kategori sangat tinggi yang ditunjukkan oleh persentasi terbesar skor tersebut.

Variabel dukungan orang tua (X2)

Berdasarkan data dukungan orang tua $\left(\mathrm{X}_{2}\right)$ memiliki rentang skor antara 15 sampai 60 , skor ratarata 37,5 dan standar deviasi 7,5. Berdasarkan hasil skor dari variabel dukungan orang tua dapat dibagi menjadi lima kriteria yaitu sangat tinggi, tinggi, sedang, rendah, dan sangat rendah. Dibawah ini adalah tabel kriteria untuk skor dukungan orang tua. 
Tabel 4.3 Kriteria Skor Variable Dukungan Orang Tua

\begin{tabular}{|l|l|}
\hline Skor & Kriteria \\
\hline $\mathrm{X} 2 \geq 48,5$ & Sangat tinggi \\
$41,25<X 2 \leq 48,75$ & Tinggi \\
$33,75<X 2 \leq 41,25$ & Sedang \\
$26,25<X 2 \leq 33,75$ & Rendah \\
& \\
& \\
\hline$X<26,25$ & Sangat rendah \\
\hline
\end{tabular}

Berdasarkan tabel kriteria dukungan orang tua di atas terdapat lima kriteria yaitu sangat tinggi berada pada skor $X \geq 48,5$, kriteria tinggi berada pada skor $41,25<X 1 \leq 48,75$, kriteria sedang berada pada skor $33,75<X 1 \leq 41,25$, kriteria rendah berada pada skor $26,5<X 1 \leq 33,75$, dan sangat rendah berada pada skor $X<26,25$. Distribusi frekuensi dan persentase dukungan orang tua dapat dilihat pada table 7.

Tabel 4.4 Distribusi Frekuensi Skor Nilai Dukungan Orang Tua

\begin{tabular}{|c|c|c|c|}
\hline Kategori & Rentang Skor & Frekuensi & Persentase \\
\hline tinggi & $48,5-60$ & 40 & 0,40 \\
\hline Tinggi & $41,25-48,5$ & 27 & 0,27 \\
\hline Sedang & $33,75-41,25$ & 7 & 0,07 \\
\hline & Total & 74 & 0,74 \\
\hline
\end{tabular}

Berdasarkan pada tabel di atas dapat diketahui $40 \%$ atau 40 mahasiswa PGMI memiliki dukungan dari orang tua pada kategori sangat tinggi; 27\% atau 27 mahasiswa dalam kategori tinggi dan $7 \%$ atau 7 mahasiswa dalam kategori sedang, sedangkan kategori rendah dan sangat rendah tidak ada. Hal ini menunjukkan bahwa orang tua memberikan dukungan sepenuhnya terhadap putraputrinya yang melanjutkan studi di PGMI STKIP Nurul Huda Sukaraja.

Sarana dan Prasarana (X3)

Berdasarkan data peluang kerja $\left(\mathrm{X}_{3}\right) 6$ memiliki rentang skor antara 10 sampai 40, skor rata-rata 25 dan standar deviasi 5. Berdasarkan hasil skor dari variable peluang kerja dapat dibagi menjadi lima criteria yaitu sangat tinggi, tinggi, rendah, dan sangat rendah. Berikut kriteria untuk skor peluang kerja.

Tabel 6. Kriteria skor variable minat

\begin{tabular}{|l|c|}
\hline Skor & Kriteria \\
\hline
\end{tabular}




\begin{tabular}{|l|l|}
\hline$X \geq 32,5$ & Sangat tinggi \\
$27,5<X 3 \leq 32,5$ & Tinggi \\
$22,5<X 3 \leq 27,5$ & Sedang \\
$22,5<X 3 \leq 17,5$ & Rendah \\
$X<17,5$ & Sangat rendah \\
& \\
\hline & \\
\hline
\end{tabular}

Berdasarkan tabel kriteria skor peluang kerja untuk lulusan PGSD UAD di atas terdapat lima kriteria yaitu sangat tinggi berada pada skor $X \geq 32,5$, kriteria tinggi berada pada skor $27,5<X 1 \leq 32,5$, kriteria sedang berada pada skor $22,5<X 1 \leq 27,5$, kriteria rendah berada pada skor $22,5<X 1 \leq 17,5$, dan sangat rendah berada pada skor $X<17,5$. Distribusi frekuensi dan persentase minat belajar mahasiswa dapat dilihat pada tabel 7.

Tabel 7. Distribusi Frekuensi Skor Peluang Kerja

\begin{tabular}{|c|r|c|c|}
\hline Kategori & \multicolumn{1}{|c|}{ Rentang } & Frekuensi & Persentase \\
\hline $\begin{array}{c}\text { Skangat } \\
\text { tinggi }\end{array}$ & $32,5-40,00$ & 35 & 0,35 \\
\hline Tinggi & $27,5-32,5$ & 25 & 0,25 \\
\hline Sedang & $22,5-27,5$ & 14 & 0,14 \\
\hline \multicolumn{2}{|c|}{ Total } & 74 & 0,74 \\
\hline
\end{tabular}

Berdasarkan pada tabel di atas dapat diketahui 35\% atau 35 siswa PGMI STKIP Nurul Huda Sukaraja memiliki keyakinan akan peluang kerja setelah lulus dari PGMI pada kategori sangat tinggi; $25 \%$ atau 25 mahasiswa yakin peluang kerjanya dalam kategori tinggi, sedangkan yang berada dalam kategori sedang ada $14 \%$ atau 14 mahasiswa.

\section{Variabel Motivasi belajar (Y)}

Berdasarkan data motivasi belajar $(\mathrm{Y})$ memiliki rentang skor antara 17 sampai 68 , skor rata-rata 42,5 dan standar deviasi 8,5. Berdasarkan hasil skor dari variabel motivasi belajar dapat dibagi menjadi lima kriteria yaitu sangat tinggi, tinggi, rendah, dan sangat rendah. Dibawah ini adalah tabel kriteria untuk skor motivasi belajar di PGMI.

Tabel 4.5 Kriteria Skor Variable Motivasi Belajar

\begin{tabular}{|l|l|}
\hline Skor & Kriteria \\
\hline
\end{tabular}




\begin{tabular}{|l|l|}
\hline$X \geq 55,25$ & Sangat tinggi \\
$46,75<X 1 \leq 55,25$ & Tinggi \\
$38,25<X 1 \leq 46,75$ & Sedang \\
$29,75<X 1 \leq 38,25$ & Rendah \\
$X<29,5$ & Sangat rendah \\
& \\
\hline & \\
\hline
\end{tabular}

Berdasarkan tabel kriteria skor motivasi belajar di PGMI STKIP Nurul Huda Sukaraja di atas terdapat lima kriteria yaitu sangat tinggi berada pada skor $X \geq 55,25$, kriteria tinggi berada pada skor $38,25<X 1 \leq 32,5$, kriteria sedang berada pada skor $22,5<X 1 \leq 27,5$, kriteria rendah berada pada skor $22,5<X 1 \leq 17,5$, dan sangat rendah berada pada skor $X<17,5$.

Tabel 4.6 Distribusi Frekuensi Skor Nilai Motivasi Belajar Mahasiswa PGMI

\begin{tabular}{|c|c|c|c|}
\hline Kategori & Rentang Skor & Frekuensi & Persentase \\
\hline $\begin{array}{c}\text { Sangat } \\
\text { tinggi }\end{array}$ & $55,25-68,00$ & 25 & 0,25 \\
\hline Tinggi & $46,75-55,25$ & 40 & 0,40 \\
\hline Sedang & $38,25-46,75$ & 9 & 0,09 \\
\hline \multicolumn{2}{|r|}{ Total } & 74 & 0,74 \\
\hline
\end{tabular}

Berdasarkan pada tabel di atas dapat diketahui 25\% atau 25 mahasiswa PGMI STKIP Nurul Huda Sukaraja memiliki motivasi belajar pada kategori sangat tinggi; dalam kategori tinggi $40 \%$ atau 40 mahasiswa dalam kategori sedang $9 \%$ atau 9 mahasiswa dalam ketegori sedang. Hal ini menunjukkan bahwa motivasi belajar mahasiswa PGMI termasuk dalam kategori tinggi yang ditunjukkan oleh persentasi terbesar skor tersebut.

Pembahasan Hasil Penelitian

Hasil analisis dari data minat belajar menunjukkan bahwa $41 \%$ responden tergolong dalam kategori sangat tinggi, sedangkan $30 \%$ tergolong tinggi dan $3 \%$ tergolong sedang. Tingginya minat belajar tersebut ditunjukkan dengan Cita-cita, Orientasi keberhasilan, Hasrat untuk belajar.

Dalam penelitian ini signifikansi pengaruh antara minat dengan motivasi ditunjukkan dengan nilai $r$ hitung yang lebih besar dari $r$ tabel $(4,554>1,664)$. Sedangkan koefisien regresinya adalah $Y=9,552$ $+0,558 X_{1}$. Dari persamaan tersebut terlihat bahwa semakin tinggi minat maka semakin tinggi motivasi belajar. Sehingga secara umum dapat terlihat bahwa mahasiswa PGMI memiliki ciri-ciri minat belajar yang tinggi sehingga akan memiliki motivasi yang tinggi pula.

Hasil analisis dari dukungan orang tua menunjukkan bahwa $40 \%$ responden tergolong dalam kategori sangat tinggi, sedangkan $27 \%$ tergolong tinggi dan $7 \%$ tergolong sedang. Tingginya dukungan orang tua tersebut ditunjukkan dengan Fasilitas yang diberikan orang tua, perhatian orang tua serta, Reward \& Punisment.

Dalam penelitian ini signifikansi pengaruh antara minat dengan motivasi ditunjukkan dengan nilai $r$ hitung $>$ dari $r$ tabel $(4,551>1,664)$. Sedangkan koefisien regresinya adalah $Y=9,552+0,443 X_{2}$. Dari persamaan tersebut terlihat bahwa semakin tinggi dukungan orang tua maka semakin tinggi motivasi belajar. Sehingga secara umum dapat terlihat bahwa mahasiswa PGMI memiliki dukungan dari orang tua yang tinggi sehingga akan memiliki motivasi yang tinggi pula.

Hasil analisis dari data sarana dan prasarana menunjukkan bahwa $25 \%$ responden tergolong dalam kategori sangat tinggi, sedangkan $40 \%$ tergolong tinggi, $9 \%$ tergolong.

Dalam penelitian ini sarana dan prasarana berpengaruh secara siignifikansi dengan motivasi, 
yang ditunjukkan dengan nilai $r$ hitung yang lebih kecil dari $r$ tabel $(1,466<1,664)$. Sedangkan koefisien regresinya adalah $Y=9,552+0,445 X_{3}$. Dari persamaan tersebut terlihat bahwa semakin tinggi sarana dan prasarana maka semakin tinggi motivasi belajar.

Hasil analisis dari data motivasi belajar menunjukkan bahwa $40 \%$ responden tergolong dalam kategori tinggi, sedangkan $40 \%$ tergolong sangat tinggi dan $9 \%$ tergolong sedang. Tingginya motivasi belajar tersebut ditunjukkan dengan tekun atau ulet dalam mengerjakan tugas-tugas yang diberikan dosen, senang bekerja juga kreatif. Hal ini sesuai dengan apa yang dijelaskan oleh Sardiman (2010: ..) bahwa motivasi dapat memberikan arahan perbuatan-perbuatan yang hendak dilakukan, sehingga dalam hubungannya dengan kegiatan belajar, adanya motivasi yang baik dalam belajar akan menunjukkan belajar yang baik pula. Bahkan motivasi belajar yang baik dalam belajar merupakan pendorong pencapaian prestasi siswa (Hamalik 1992: 172).

Dalam penelitian ini persamaan koefisien regresinya adalah $Y=9,552+0,558 X_{1}+0,443 X_{2 .}+$ $0,445 X_{3}$. Yang berarti bahwa jika minat, dukungan orang tua dan sarana dan prasarana maka motivasi belajar yang diperoleh seorang mahasiswa sebesar 9,552, sedangkan jika terjadi kenaikan skor minat maka motivasi belajar mahasiswa akan meningkat sebesar 0,558 dan jika terjadi kenaikan skor dukungan orang tua maka motivasi belajar mahasiswa akan meningkat sebesar 0,443 terjadi kenaikan skor sarana dan prasarana maka motivasi belajar mahasiswa akan meningkat sebesar 0,445.

\section{PENUTUP}

Berdasarkan hasil penelitian, maka dapat ditarik kesimpulan sebagai berikut :

Terdapat pengaruh antara minat terhadap motivasi belajar mahasiswa PGMI STKIP Nurul Huda Sukaraja dengan nilai t hitung 4,554. Hal ini mengindikasikan semakin tinggi minat belajar yang dimiliki maka motivasi belajar yang dimiliki juga semakin tinggi.

Terdapat pengaruh antara dukungan orang tua terhadap motivasi belajar mahasiswa PGMI dengan nilai t hitung 4,551. Hal ini juga mengindikasikan bahwa semakin tinggi dukungan orang tua mahasiswa maka motivasi belajar yang dimiliki juga semakin tinggi.

Terdapat pengaruh antara sarana dan prasarana terhadap motivasi belajar mahasiswa PGMI dengan nilai t hitung 4,447. Hal mengindikasikan bahwa sarana dan prasarana menjadi bagian yang dapat memotivasi belajar para mahasiswa.

\section{UCAPAN TERIMAKASIH}

STKIP Nurul Huda di Sukaraja yang telah mendanai menelitian ini.

\section{DAFTAR PUSTAKA}

Arikunto, 2013. Prosedur Penelitian Suatu pendekatan Praktik. Jakarta:Pt. Rineka Cipta Dimyati dan Mudjiono. 2006. Belajar dan Pembelajran. Jakarta: PT Rajagrafindo Persada. Minarti, Sri. 2011. Manajemen Sekolah: Mengelola Lembaga Pendidikan Secara Mandiri. Yogyakarta: Ar-Ruzz Media.

Nashar. 2004. Peranan Motivasi dan Kemampuan Awal dalam Kegiatan Pembelajaran. Jakarta: Delia Press.

Purwanto. 2010. Psikologi Pendidikan. Bandung:Rosdakarya.

Sardiman. 2012. Interaksi dan Motivasi Belajar Mengajar. Jakarta: Rajawali Pers

Shalahudin. M. 2000. Pengantar Psikologi pendidikan. Surabaya:PT. Bina IImu Slameto. 2010. Belajar dan Faktor-Faktor yang Mempengaruhinya. Jakarta: Rineka Cipta. W.S Winkel. 1996. Psikologi Pengajaran. (akarta: Gransindo. Cetakan 4 